\title{
Pelagic and littoral cladocerans (Crustacea, Anomopoda and Ctenopoda) from reservoirs of the Northwest of São Paulo State, Brazil
}

\author{
Maria Stela Maioli Castilho-Noll ${ }^{1,2}$, Carolina Figueira Câmara ${ }^{1}$, \\ Maira Favaron Chicone ${ }^{I} \&$ Érico Hissashi Shibata ${ }^{I}$ \\ ${ }^{1}$ Departamento de Zoologia e Botânica - IBILCE, Universidade Estadual Paulista - UNESP, \\ Rua Cristóvão Colombo, 2265, Jardim Nazareth, CEP 15054-000 São José do Rio Preto, SP, Brasil \\ ${ }^{2}$ Corresponding author: Maria Stela Maioli Castilho-Noll, e-mail: mstela@ibilce.unesp.br
}

CASTILHO-NOLL, M.S.M., CÂMARA, C.F., CHICONE, M.F. \& SHIBATA, E.H. Pelagic and littoral cladocerans (Crustacea, Anomopoda and Ctenopoda) from reservoirs of the Northwest of São Paulo State, Brazil. Biota Neotrop. 10(1): http://www.biotaneotropica.org.br/v10n1/en/abstract?article+bn00310012010.

\begin{abstract}
There are few studies on the zooplankton from the northwestern region of São Paulo State, Brazil, compared to other regions of the State. Cladocerans are a very representative zooplankton group with high species diversity. Most of this diversity can be found at littoral zones of lakes and reservoirs, especially those occupied by macrophytes. This study was part of a thematic project FAPESP/BIOTA Program - The Virtual Institute of Biodiversity (www.biotasp.org.br), and its aim is to catalogue and analyze the distribution of cladoceran species (Crustacea, Anomopoda and Ctenopoda) in pelagic and littoral zones from small reservoirs in the northwest of the São Paulo State, in dry and rainy seasons. Zooplankton samplings were carried out in littoral and pelagic zone of 10 small shallow reservoirs (mean depth: $2.8 \mathrm{~m}$ ) using a plankton $45 \mu \mathrm{m}$ mesh net. Water physical and chemical parameters were also monitored with a multiparameter Horiba U10. $\mathrm{pH}$ and dissolved oxygen concentration were lower at rainy than dry seasons, indicating high decomposition rates of organic matter introduced from the rural environment, being the main factor contributing to reservoirs' eutrophication. Fifty eight cladocerans species were recorded, with four new occurrences for the São Paulo State. This high richness contrasts with the high devastation of the northwestern region in the State. During the two seasons, littoral zones presented higher cladoceran richness and diversity than pelagic zone. Littoral zones with higher macrophytes diversity also showed higher cladocerans richness and diversity than that with low macrophyte diversity. Littoral and pelagic zones comparisons emphasized the importance of studies on different regions of the aquatic environments, confirming the elevated richness in the littoral zone, as reported in previous works. This study revealed also the strong influence of the macrophyte community and the adjacent terrestrial environment, which is occupied by forest or agriculture.
\end{abstract}

Keywords: cladocerans, Chydoridae, littoral zone, macrophyte, Northwest of São Paulo State, shallow lakes.

CASTILHO-NOLL, M.S.M., CÂMARA, C.F., CHICONE, M.F. \& SHIBATA, E.H. Cladóceros (Crustacea, Anomopoda e Ctenopoda) pelágicos e litorâneos em reservatórios na região noroeste do estado de São Paulo, Brasil. Biota Neotrop. 10(1): http://www.biotaneotropica.org.br/v10n1/pt/abstract?article+bn00310012010.

Resumo: A região noroeste paulista é uma das regiões com menor quantidade de dados sobre o zooplâncton, comparado a outras regiões do estado. Os Cladocera constituem um grupo bastante representativo do zooplâncton, apresentando elevada diversidade de espécies. A maior parte desta diversidade pode ser encontrada nas regiões litorâneas de lagos e reservatórios, especialmente aquelas ocupadas por muitas macrófitas. Como parte de um projeto temático mais amplo (Programa Biota-Fapesp - Instituto Virtual da Biodiversidade, www.biotasp.org. br), o presente trabalho tem o objetivo de caracterizar as comunidades de cladóceros (Crustacea, Anomopoda e Ctenopoda) pelágicos e litorâneos presentes em pequenos reservatórios na região noroeste do estado de São Paulo, nas estações seca e chuvosa. As amostragens foram realizadas tanto na zona litorânea quanto pelágica de 10 pequenos reservatórios rasos (média de $2,8 \mathrm{~m}$ ), através de arrastos verticais com rede de plâncton de $45 \mu \mathrm{m}$ de malha. Parâmetros físicos e químicos da água também foram avaliados utilizando-se o aparelho Horiba U10. As concentrações de oxigênio e o pH foram mais baixos na estação chuvosa, indicando maiores taxas de decomposição. A entrada de matéria proveniente do ambiente rural pode ser o principal fator que contribui para a eutrofização dos reservatórios. No total, foram identificadas 58 espécies de cladóceros, sendo que destas, quatro constituem novas ocorrências para o estado de São Paulo. Esta elevada riqueza contrapõe-se com o fato de que a região noroeste paulista tem sido considerada uma das mais devastadas do estado. Maiores valores de riqueza e diversidade foram observados na zona litorânea, comparado à zona pelágica, durante as duas estações. Zonas litorâneas com maior diversidade de macrófitas também apresentaram maiores riqueza e diversidade de espécies de cladóceros do que zonas com menor diversidade de macrófitas. As comparações entre as zonas litorâneas e pelágicas evidenciaram a importância dos estudos nos diferentes compartimentos dos ambientes aquáticos, confirmando a elevada riqueza na zona litorânea, já relatada em tantos outros trabalhos, bem como revelando a forte influência da comunidade de macrófitas e do ambiente terrestre adjacente.

Palavras-chave: cladóceros, Chydoridae, zona litorânea, macrófitas, noroeste paulista, lagos rasos. 


\section{Introduction}

Zooplankton microcrustaceans studies in São Paulo State have been intensely carried out by several authors, especially in the eighties and nineties (Matsumura-Tundisi \& Rocha 1983, Arcifa 1984, Matsumura-Tundisi 1984, Sendacz 1984, Arcifa et al. 1992, 1998, Henry \& Nogueira 1999, Sendacz \& Kubo 1999). Revision presenting sampling places (Rocha et al. 1995) and species list (Rocha \& Guntzel 1999) for São Paulo State revealed the lack of data for some regions. Ismael et al. (1999) estimated that $c a$. $66 \%$ of Brazilian zooplankton fauna were reported for the State of São Paulo. It could be possible increase this number with the continuity of species cataloguing in another areas of the State.

In relation to zooplankton communities of the state of São Paulo, the northwest is one of the least investigated regions, which still presents scarce literature on the group and a lack of information about species composition of microcrustaceans and rotifers. Silva \& Matsumura-Tundisi (2005) paper on copepods and Santos-Wisniewski et al. (2008) on Cladocera can be considered pioneers on zooplankton works to northwest of São Paulo.

Cladocerans are a very representative zooplankton group with high species diversity. However, most of this diversity can be found in the littoral regions of lakes and reservoirs, especially those occupied by many macrophytes, which present high environmental heterogeneity, resulting in high biodiversity. According to Rocha et al. (1995), comparisons between the littoral and pelagic zones are important aspects to consider in zooplankton studies for a better assessment of the diversity of these organisms.

Littoral zones are intensively affected by the processes that take place in both pelagic regions and in land (Nogueira et al. 1993), with a great importance for the management of water quality (Straskraba et al. 1993). However, even though high diversity in these zones is frequently reported, the biology and the ecology of the littoral zoo- plankton are not well-known (Nogueira et al. 2003, Maia-Barbosa et al. 2008) what, according to Lemly \& Dimmick (1982), can be attributed to the lack of efficient and standardized sampling methods.

As part of a broader project (FAPESP/BIOTA Program - The Virtual Institute of Biodiversity, www.biotasp.org.br), which intends to catalogue the species of several groups of organisms in forest fragments in the northwest of São Paulo State, the present work aims at cataloguing and analyzing the distribution of cladocerans (Crustacea, Anomopoda and Ctenopoda) in pelagic and littoral zones from small reservoirs in the northwest of São Paulo State.

\section{Material and Methods}

\section{Study area}

Samplings were taken in ten small reservoirs in the northwestern region of the São Paulo State (Figure 1), during the dry season of 2007 and rainy season of 2008. Climate in the region is Tropical Hot and Rainy (Aw of Köppen's classification), with a dry season from April to September and the rainy one from October to March. Northwestern region of São Paulo has been considered as one of the most devastated of the State (Kronka et al. 1993). The original vegetation, formed by seasonal semideciduous forest and savanna - which has being replaced by pastures, diversified cultures or urbane areas -is currently restricted to $9 \%$ of its original area. The studied reservoirs have a total area of ca. 0.1 ha, in average, and have been used as water source for animals and irrigation in rural areas. Table 1 presents the sampling stations and some characteristics of the studied reservoirs. At sampling station G9, three reservoirs were sampled.

\section{Samplings and quantitative zooplankton evaluation}

Zooplankton was sampled using a plankton $45 \mu \mathrm{m}$ mesh net in sites at littoral and pelagic zones, in all reservoirs and both seasons. In

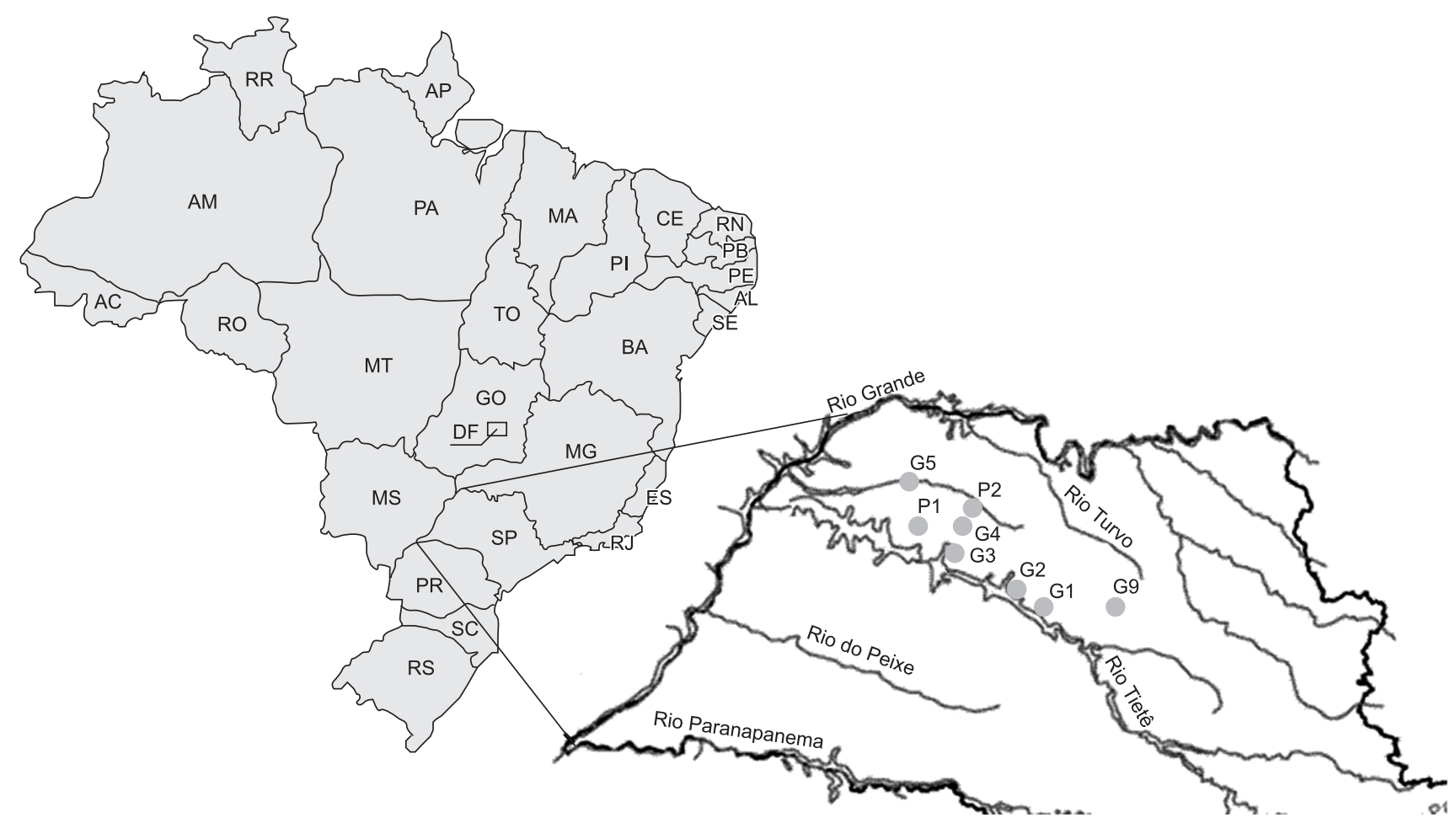

Figure 1. Brazilian map showing São Paulo State with the locations of the studied reservoirs, in the northwestern region of the State.

Figura 1. Mapa do Brasil mostrando o Estado de São Paulo com as localizações dos reservatórios estudados na região noroeste. 
Table 1. Locations, depth and edge characteristics of the reservoir studied.

Tabela1. Localizações, profundidades e características da borda dos reservatórios estudados.

\begin{tabular}{|c|c|c|c|c|}
\hline Reservoirs & Cities in São Paulo State & Coordinates & Depth & Edge \\
\hline $\mathrm{P} 1$ & Vicentinópolis & $\begin{array}{l}50^{\circ} 20^{\prime} 51^{\prime \prime} \mathrm{W} \\
20^{\circ} 56^{\prime} 00^{\prime \prime} \mathrm{S}\end{array}$ & $\begin{array}{l}\text { Littoral } 0.5 \mathrm{~m} \\
\text { Pelagic } 1.8 \mathrm{~m}\end{array}$ & Forest and culture \\
\hline $\mathrm{P} 2$ & Macaubal & $\begin{array}{l}49^{\circ} 56^{\prime} 13^{\prime \prime} \mathrm{W} \\
20^{\circ} 44^{\prime} 40^{\prime \prime} \mathrm{S}\end{array}$ & $\begin{array}{l}\text { Littoral } 0.3 \mathrm{~m} \\
\text { Pelagic } 2.4 \mathrm{~m}\end{array}$ & Culture \\
\hline G1 & Novo Horizonte & $\begin{array}{l}49^{\circ} 18^{\prime}, 29^{\prime \prime} \mathrm{W} \\
21^{\circ} 30^{\prime} 10^{\prime \prime} \mathrm{S}\end{array}$ & $\begin{array}{l}\text { Littoral } 0.8 \mathrm{~m} \\
\text { Pelagic } 2.1 \mathrm{~m}\end{array}$ & Culture \\
\hline G2 & Sales & $\begin{array}{l}49^{\circ} 29^{\prime} 59^{\prime \prime} \mathrm{W} \\
21^{\circ} 25^{\prime} 33^{\prime \prime} \mathrm{S}\end{array}$ & $\begin{array}{l}\text { Littoral } 0.3 \mathrm{~m} \\
\text { Pelagic } 2.4 \mathrm{~m}\end{array}$ & Forest \\
\hline G3 & Planalto & $\begin{array}{l}49^{\circ} 58^{\prime} 41^{\prime \prime} \mathrm{W} \\
21^{\circ} 00^{\prime} 54^{\prime \prime} \mathrm{S}\end{array}$ & $\begin{array}{l}\text { Littoral } 0.7 \mathrm{~m} \\
\text { Pelagic } 3.8 \mathrm{~m}\end{array}$ & Forest and culture \\
\hline G4 & União Paulista & $\begin{array}{l}49^{\circ} 55^{\prime} 17^{\prime \prime} \mathrm{W} \\
20^{\circ} 54^{\prime} 28^{\prime \prime} \mathrm{S}\end{array}$ & $\begin{array}{l}\text { Littoral } 2.1 \mathrm{~m} \\
\text { Pelagic } 4.9 \mathrm{~m}\end{array}$ & Culture \\
\hline G5 & Magda & $\begin{array}{l}50^{\circ} 11^{\prime} 43^{\prime \prime} \mathrm{W} \\
20^{\circ} 32^{\prime} 00^{\prime \prime} \mathrm{S}\end{array}$ & $\begin{array}{l}\text { Littoral } 0.2 \mathrm{~m} \\
\text { Pelagic } 1.3 \mathrm{~m}\end{array}$ & Forest and culture \\
\hline G91 & Matão & $\begin{array}{l}48^{\circ} 33^{\prime} 12^{\prime \prime} \mathrm{W} \\
21^{\circ} 36^{\prime} 18^{\prime \prime} \mathrm{S}\end{array}$ & $\begin{array}{l}\text { Littoral } 1.3 \mathrm{~m} \\
\text { Pelagic } 2.4 \mathrm{~m}\end{array}$ & Forest \\
\hline G92 & Matão & $\begin{array}{l}48^{\circ} 32^{\prime} 47^{\prime \prime} \mathrm{W} \\
21^{\circ} 31^{\prime} 00^{\prime \prime} \mathrm{S}\end{array}$ & $\begin{array}{l}\text { Littoral } 0.6 \mathrm{~m} \\
\text { Pelagic } 1.9 \mathrm{~m}\end{array}$ & Forest \\
\hline G93 & Matão & $\begin{array}{l}48^{\circ} 30^{\prime} 33^{\prime \prime} \mathrm{W} \\
21^{\circ} 36^{\prime} 25^{\prime \prime} \mathrm{S}\end{array}$ & $\begin{array}{l}\text { Littoral } 0.2 \mathrm{~m} \\
\text { Pelagic } 2.5 \mathrm{~m}\end{array}$ & Culture \\
\hline
\end{tabular}

Table 2. Physical and chemical data of the water in the reservoirs, at the dry and rainy season.

Tabela 2. Dados físicos e químicos da água nos reservatórios, nas estações seca e chuvosa.

\begin{tabular}{lcrrrrrrrrrr}
\hline & & P1 & P2 & G1 & G2 & G3 & G4 & G5 & G91 & G92 & G93 \\
\hline Depth $(\mathrm{m})$ & Dry & 1.8 & 2.4 & 2.1 & 2.4 & 3.8 & 4.9 & 1.3 & 2.4 & 1.9 & 2.5 \\
& Rainy & 2.2 & 2.3 & 1.8 & - & 4.5 & 4.9 & 1.9 & - & 3.2 & 3.5 \\
Secchi $(\mathrm{m})$ & Dry & 1.8 & 0.2 & 2.0 & 1.0 & 1.9 & 2.6 & 0.9 & 1.2 & 0.8 & 1.1 \\
& Rainy & 2.2 & 0.6 & 0.8 & - & 3.0 & 2.6 & 1.4 & - & 0.8 & 1.2 \\
Temperature $\left({ }^{\circ} \mathrm{C}\right)$ & Dry & 23.5 & 18.8 & 22.4 & 23.0 & 18.1 & 19.0 & 25.1 & 22.9 & 23.2 & 23.3 \\
& Rainy & 24.8 & 24.5 & 25.1 & - & 25.7 & 26.1 & 25.6 & - & 25.2 & 24.5 \\
$\mathrm{pH}$ & Dry & 6.3 & 6.4 & 5.8 & 7.8 & 5.9 & 6.2 & 6.8 & 5.7 & 6.3 & 7.9 \\
& Rainy & 5.0 & 5.6 & 5.5 & - & 5.7 & 6.2 & 6.3 & - & 5.4 & 6.6 \\
Conductivity $\left(\mu S . \mathrm{cm}^{-1}\right)$ & Dry & 12.0 & 10.0 & 2.0 & 54.0 & 20.0 & 10.0 & 43.0 & 16.0 & 42.0 & 55.0 \\
& Rainy & 17.3 & 27.0 & 4.0 & - & 13.3 & 25.5 & 100.7 & - & 48.0 & 141.7 \\
OD $\left(\mathrm{mg} . \mathrm{L}^{-1}\right)$ & Dry & 5.8 & 5.8 & 6.1 & 6.6 & 5.6 & 6.8 & 3.8 & 2.6 & 3.7 & 8.0 \\
& Rainy & 4.8 & 5.5 & 5.7 & - & 3.0 & 3.6 & 1.6 & - & 1.2 & 3.8 \\
\hline
\end{tabular}

three of the reservoirs, where there were different kinds of vegetation on the edge, such as forest and cultures -mainly sugar-cane or pasture-, both types of littoral were sampled and were identified as "forest littoral" and "culture littoral". We considered littoral zones with more than two species of macrophyte as high diversity macrophyte zones and up to two species as low diversity macrophyte zone.

Species identification was carried out under optical microscope, using specific identification keys (Smirnov 1996, Elmoor-Loureiro 1997) and papers with species details (Elmoor-Loureiro et al. 2004). Cladocerans were counted in $1 \mathrm{ml}$-subsamples taken with the pipette, placed in the counting chamber and counted using a stereoscopic microscope. At least sixty individuals were numbered in each subsample; the coefficient of variation did not exceed 0.20 , as recommended (McCauley 1984). Low-density samples were fully counted.

Richness index, alpha diversity (Shannon-Wiener), Simpson diversity and equitability index were calculated following recom- mendations of Magurran (2004). $t$-test was used to compare data from littoral and pelagic zones, as well as between areas with different kinds of adjacent terrestrial environment. In order to compare the cladoceran fauna among the sampling sites, a cluster analysis (UPGMA, mean character difference) was conducted using MVSP Program (Kovach 1993).

Environmental factors, such as depth and water transparency were measured with Secchi disc, while physical and chemical parameters (temperature, dissolved oxygen, $\mathrm{pH}$ and conductivity), were obtained with a multiparameter Horiba U-10.

\section{Results}

\section{Physical and chemical parameters}

In general, reservoirs presented low depth, with mean of $2.8 \mathrm{~m}$; as expected, small increases occurred during the rainy season (Table 2). 
Water transparency was very low in some reservoirs, as in P2 at dry season, but high for others, as in G3 and G4. In the most reservoirs, transparency was higher at rainy than dry season. Water temperatures in reservoirs varied from 18.1 to $25.1^{\circ} \mathrm{C}$ at dry season and increased to 24.5 to $26.1^{\circ} \mathrm{C}$ at rainy season. At dry season, most of reservoirs had $\mathrm{pH}$ values higher than 6 , but at the rainy, $\mathrm{pH}$ values were low than 6 . Almost all reservoirs had low conductivity values - ca. $20 \mu \mathrm{S} . \mathrm{cm}^{-1}$ but at rainy season, G5 and G93 had conductivity above 100 and $140 \mu \mathrm{S} . \mathrm{cm}^{-1}$, respectively. Dissolved oxygen concentrations were lower at the rainy than the dry season in all reservoirs. Concentra- tions varied from 2.6 to $8.0 \mathrm{mg} . \mathrm{L}^{-1}$ at dry and from 1.2 to $5.7 \mathrm{mg} . \mathrm{L}^{-1}$ at rainy season.

\section{Zooplankton}

All cladoceran species found in the reservoirs at both seasons are listed in the Table 3. Fifty eight species were recorded, with four new records for São Paulo State.

Several species were exclusive from the littoral zones, most belonging to Chydoridae family (Table 3). Many species were observed

Table 3. List of cladoceran species, with his respective total densities in the littoral $(\mathrm{L})$ and pelagic $(\mathrm{P})$ zones from reservoirs in the northwestern region of São Paulo State, during dry and rainy season.

Tabela 3. Lista das espécies de cladóceros, com suas respectivas densidades totais nas zonas litorânea (L) e pelágica (P) de reservatórios na região noroeste do Estado de São Paulo, durante as estações seca e chuvosa.

\begin{tabular}{|c|c|c|c|c|c|}
\hline & & \multicolumn{2}{|c|}{ Dry Season } & \multicolumn{2}{|c|}{ Rainy Season } \\
\hline & & $\mathbf{L}$ & $\mathbf{P}$ & $\mathbf{L}$ & $\mathbf{P}$ \\
\hline \multirow[t]{5}{*}{ SIDIDAE } & Diaphanosoma brevireme Sars 1901 & & & & \\
\hline & Diaphanosoma birgei Korineck, 1981 & & & & \\
\hline & Diaphanosoma spinulosum Herbst, 1967 & & & & \\
\hline & Pseudosida bidentada Herrick, 1884 & & - & & \\
\hline & Latonopsis australis Sars, 1888 * & - & - & & - \\
\hline \multirow[t]{3}{*}{ BOSMINIDAE } & Bosmina hagmanni Stingelin, 1904 & - & & & - \\
\hline & Bosmina freyi De Melo \& Hebert, 1994 & & & - & - \\
\hline & Bosmina tubicen Brehm, 1953 & - & - & & \\
\hline MOINIDAE & Moina minuta Hansen, 1899 & & & & \\
\hline \multirow[t]{11}{*}{ DAPHNIIDAE } & Ceriodaphnia cornuta cornuta Sars, 1886 & & - & & \\
\hline & Ceriodaphnia cornuta rigaudi Sars, 1886 & & & & \\
\hline & Ceriodaphnia silvestrii Daday, 1902 & & & & \\
\hline & Ceriodaphnia pulchella Sars, 1862 & & - & - & - \\
\hline & Ceriodaphnia richardi Sars, 1901 & & - & - & - \\
\hline & Daphnia gessneri Herbst, 1967 & & & & \\
\hline & Daphnia ambigua Scourfield, 1947 & - & & & \\
\hline & Scapholeberis armata Herrick, 1882 & & & - & - \\
\hline & Simocephalus daphnoides Herrick, 1883 & & & & - \\
\hline & Simocephalus latirostris Stingelin, $1906 *$ & & - & - & - \\
\hline & Simocephalus serrulatus (Koch, 1841) & - & - & & - \\
\hline ILYOCRYPTIDAE & Ilyocryptus spinifer Herrick, 1882 & & & & \\
\hline \multirow[t]{4}{*}{ MACROTHRICIDAE } & Macrothrix elegans Sars, 1901 & & & & - \\
\hline & Macrothrix laticornis (Jurine, 1820) & & - & & - \\
\hline & Macrothrix paulensis (Sars, 1901) & & & & \\
\hline & Macrothrix spinosa King, 1853 & & - & & \\
\hline CHYDORIDAE & & - & - & - & - \\
\hline \multirow[t]{7}{*}{ CHYDORINAE } & Alonella lineolata Sars, 1901 & & - & - & - \\
\hline & Alonella brasiliensis Bergamin, 1935 & - & - & & - \\
\hline & Alonella dentifera Sars, 1901 & - & - & & - \\
\hline & Alonella dadayi Birge, 1910 & - & - & & \\
\hline & Alonella dentifera Sars, 1901 & - & - & - & \\
\hline & Chydorus pubescens Sars, 1901 & & - & & - \\
\hline & Chydorus nitidulus (Sars, 1901) & & & - & - \\
\hline
\end{tabular}

\footnotetext{
* New records for São Paulo State

$\mathrm{L}=$ Littoral zone; $\mathrm{P}=$ Pelagic zone

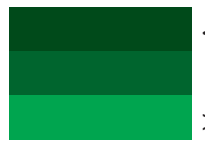

$<100$ ind.$/ \mathrm{m}^{3}$
$101-1000$ ind. $/ \mathrm{m}^{3}$
$>1000$ ind. $/ \mathrm{m}^{3}$
} 
Table 3. Continued..

\begin{tabular}{|c|c|c|c|c|c|}
\hline & & \multicolumn{2}{|c|}{ Dry Season } & \multicolumn{2}{|c|}{ Rainy Season } \\
\hline & & $\mathbf{L}$ & $\mathbf{P}$ & $\mathbf{L}$ & $\mathbf{P}$ \\
\hline \multirow{26}{*}{ ALONINAE } & Chydorus dentifer Daday, 1905 & & - & & - \\
\hline & Chydorus eurynotus Sars, 1901 & - & - & & - \\
\hline & Dadaya macrops (Dady, 1898) & & - & - & - \\
\hline & Disparalona leptorhyncha (Smirnov, 1974) & - & - & & - \\
\hline & Ephemeroporus barroisi (Richard, 1894) & & & & \\
\hline & Ephemeroporus hybridus (Daday, 1905) * & & - & & - \\
\hline & Ephemeroporus tridentatus (Bergamin, 1931) & & & & - \\
\hline & Pseudochydorus globosus (Baird, 1850) & & - & & - \\
\hline & Acroperus harpae Baird, 1843 & & - & & - \\
\hline & Alona glabra Guerne \& Richard, 1893 & & & & - \\
\hline & Alona guttata Sars, 1862 & & & - & - \\
\hline & Alona monacantha Sars, 1901 & & - & & \\
\hline & Alona poppei Richard, 1897 & & - & & - \\
\hline & Alona ossiani Sinev, 1998 & & - & & - \\
\hline & Alona intermedia (Sars, 1862) & & - & & \\
\hline & Alona verrucosa (Sars, 1901) & & - & & \\
\hline & Alona iheringula Sars, 1901 & - & - & & - \\
\hline & Camptocercus dadayi Stingelin, 1913 & & - & - & - \\
\hline & Euryalona orientalis (Daday, 1898) & & - & - & - \\
\hline & Graptoleberis occidentalis Sars, 1901 & & - & - & - \\
\hline & Karualona mulleri (Richard, 1897) & & - & - & - \\
\hline & Kurzia polyspina Hudec, 2000 & - & & - & - \\
\hline & Leydigia striata Birabén, 1939 & & - & - & - \\
\hline & Leydigiopsis brevirostris Brehm, $1938 *$ & & - & & \\
\hline & Leydigiopsis megalops Sars, 1901 & & - & - & - \\
\hline & Notoalona sculpta (Sars, 1901) & - & - & & - \\
\hline Total (ind $\left./ \mathrm{m}^{3}\right)$ & & 118762.2 & 12147.4 & 11646.4 & 49713.2 \\
\hline \multicolumn{6}{|c|}{ New records for São Paulo State } \\
\hline \multicolumn{6}{|c|}{$\mathrm{L}=$ Littoral zone; $\mathrm{P}=$ Pelagic zone } \\
\hline \multicolumn{6}{|c|}{$<100$ ind.$/ \mathrm{m}^{3}$} \\
\hline \multicolumn{6}{|c|}{$101-1000$ ind.$/ \mathrm{m}^{3}$} \\
\hline & $>1000 \mathrm{ind} . / \mathrm{m}^{3}$ & & & & \\
\hline
\end{tabular}

Table 4. Cladoceran species richness (S), Shannon index (H'), Simpson's dominance (D) and evenness (e) in littoral and pelagic zone, during dry and rainy season.

Tabela 4. Riqueza (S), índice de Shannon (H'), dominância de Simpson (D) e equitabilidade (e) das espécies de cladóceros das zonas litorâneas e pelágicas dos reservatórios, durante as estações seca e chuvosa.

\begin{tabular}{cccc}
\hline & & Dry & Rainy \\
\hline $\mathrm{S}$ & Littoral & $9.0 \pm 3.0$ & $10.0 \pm 4.0$ \\
& Pelagic & $3.0 \pm 1.0$ & $4.3 \pm 2.3$ \\
$\mathrm{H}$, & Littoral & $1.3 \pm 0.7$ & $1.5 \pm 0.7$ \\
& Pelagic & $0.7 \pm 0.5$ & $1.0 \pm 0.7$ \\
$\mathrm{D}$ & Littoral & $0.4 \pm 0.3$ & $0.3 \pm 0.3$ \\
& Pelagic & $0.6 \pm 0.3$ & $0.5 \pm 0.3$ \\
$\mathrm{e}$ & Littoral & $0.7 \pm 0.2$ & $0.6 \pm 0.3$ \\
& Pelagic & $0.7 \pm 0.2$ & $0.8 \pm 0.2$ \\
\hline
\end{tabular}

at littoral and pelagic, during two seasons, but some of them occurred exclusively at dry (15) or at rainy season (11).

Richness \& diversity of species were higher in littoral zones than pelagic ones (Table 4). At dry season, statistically significant differences between the littoral and pelagic zones were observed in species richness $(\mathrm{t}=2.97, \mathrm{p}=0.01, \mathrm{n}=10)$ and in diversity $(\mathrm{t}=2.3$, $\mathrm{p}=0.03, \mathrm{n}=10)$.

At rainy season, cladoceran richness was also statistically higher in the littoral zone than in the pelagic one $(\mathrm{t}=3.17, \mathrm{p}=0.006, \mathrm{n}=10)$ (Table 4). Other indexes showed no statistical differences.

At dry season, Sididae, Bosminidae, Moinidae and Daphniidae presented higher number of species in pelagic zone than in littoral, on the contrary of Ilyocriptidae, Macrothricidae and Chydoridae that were more representative in the littoral (Figure 2).

At rainy season, all the families, except Daphniidae, were more representative in the littoral zone (Figure 3). High number of Chydoridae species occurred at both seasons and especially in the littoral zone (Figures 2 and 3).

Density and species richness were higher in the littoral, especially at the dry season. Sididae, Bosminidae and Daphniidae were more 

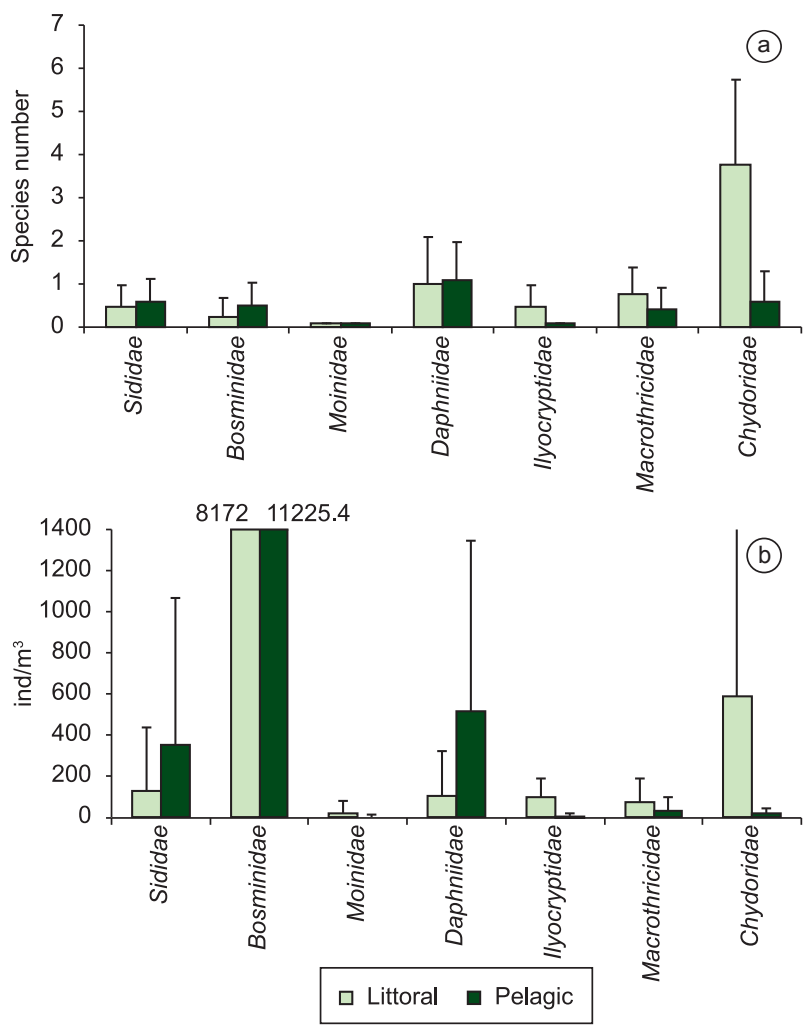

Figure 2. Species number a) and densities b) of the Cladocera families found in littoral and pelagic zones in the reservoirs studied, at the dry station.

Figura2. Número de espécies a) e densidade b) das famílias de Cladocera encontradas nas zonas litorânea e pelágica nos reservatórios estudados, na estação seca.
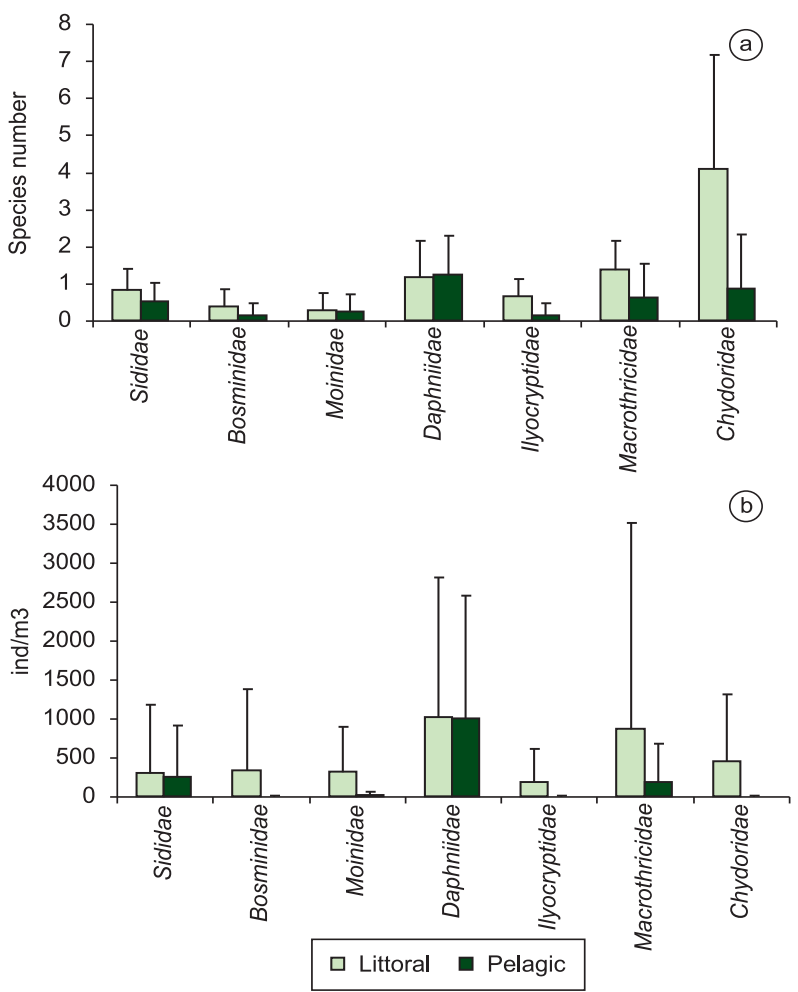

Figure 3. Species number a) and densities b) of the Cladocera families found in littoral and pelagic zones in the reservoirs studied, at the rainy station.

Figure 3. Número de espécies a) e densidade b) das famílias de Cladocera encontradas nas zonas litorânea e pelágica nos reservatórios estudados, na estação chuvosa.
Table 5. Cladoceran species richness (S) and Shannon index (H') in littoral zones with different macrophyte diversities, during dry and rainy season.

Tabela 5. Riqueza (S) e índice de Shannon (H') das espécies de Cladocera encontradas nas zonas litorâneas com diferentes diversidades de macrófitas, durante as estações seca e chuvosa.

\begin{tabular}{ccc}
\hline & $\begin{array}{c}\text { High diversity } \\
\text { of macrophyte* }\end{array}$ & $\begin{array}{c}\text { Low diversity } \\
\text { of macrophyte } * *\end{array}$ \\
\hline $\mathrm{S}$ & $10.4 \pm 3.3$ & $4.5 \pm 1.5$ \\
$\mathrm{H}$, & $1.5 \pm 0.7$ & $1.0 \pm 0.7$ \\
\hline * With more than two species, including floating and rooted. \\
** Up to two species.
\end{tabular}

Table 6. Cladoceran species richness (S) and Shannon index (H') in littoral zones with different kinds of edge, during dry and rainy season.

Tabela 6. Riqueza (S) e índice de Shannon (H') das espécies de Cladocera encontradas nas zonas litorâneas com diferentes tipos de borda, durante as estações seca e chuvosa.

\begin{tabular}{cccccr}
\hline & \multicolumn{2}{c}{ Dry } & & \multicolumn{2}{c}{ Rainy } \\
\cline { 2 - 3 } \cline { 5 - 6 } & $\begin{array}{c}\text { Forest } \\
\text { littoral }\end{array}$ & $\begin{array}{c}\text { Culture } \\
\text { littoral }\end{array}$ & & $\begin{array}{c}\text { Forest } \\
\text { littoral }\end{array}$ & $\begin{array}{c}\text { Culture } \\
\text { littoral }\end{array}$ \\
\hline $\mathrm{S}$ & $8.3 \pm 1.53$ & $4.7 \pm 1.53$ & & $9.3 \pm 5.8$ & $10.3 \pm 3.8$ \\
$\mathrm{H}^{\prime}$ & $1.8 \pm 0.06$ & $1.0 \pm 0.8$ & & $1.1 \pm 0.9$ & $1.5 \pm 0.6$ \\
\hline
\end{tabular}

abundant in the pelagic zone and Ilyocriptidae, Macrothricidae and Chydoridae in the littoral (Figure 2). At rainy season, on the other hand, all families were more abundant in the littoral than the pelagic zone (Figure 3).

A statistically significant difference $(\mathrm{t}=4.5, \mathrm{p}=0.001, \mathrm{n}=11)$ was found between the cladoceran species richness and diversity of the littoral zone with high macrophytes diversity than with low macrophytes diversity (Table 5).

Cladoceran species richness between littoral zones with forest and that one with cultures on the adjacent terrestrial environment was also statistically different $(t=2.9, p=0.04, n=3)$ at dry season (Table 6). Species considered typically filter feeders as from the genus Daphnia, Ceriodaphnia and Diaphanosoma were not observed in culture littoral, but only in pelagic and forest littoral. At rainy season, richness and diversity were similar among different edges (Table 6).

Cluster analysis resulted in a group with $60 \%$ of similarity, which had most of the littoral stations. Another group with $100 \%$ of similarity was shaped by only littoral sites (Figure 4).

\section{Discussion}

Small and shallow reservoirs might have high rates of decomposition due to the high eutrophication. High concentrations of $\mathrm{CO}_{2}$ and reduced $\mathrm{pH}$ can be found in flooded regions, with elevated concentrations of particulate or dissolved organic matter (Wetzel 2001).

Physical and chemical data observed in reservoirs allow us to classify them as shallow lakes, with high decomposition rates mainly at rainy season, when $\mathrm{pH}$ and DO were reduced. Since they are in rural environments they are also subject to an input of organic and inorganic material, very often rich on nitrogen and phosphorus originated from the adjacent cultures. Fertilizers can be considered as the main cause of eutrophication of these aquatic environments, resulting in high decomposition rates. The increase of nitrogen and phosphorus produced by the human activity enhances natural eutrophication (Tundisi \& Matsumura-Tundisi 2008).

In general, comparison between pelagic and littoral zones communities showed differences on composition and abundance of cladoceran populations, especially at dry season. 


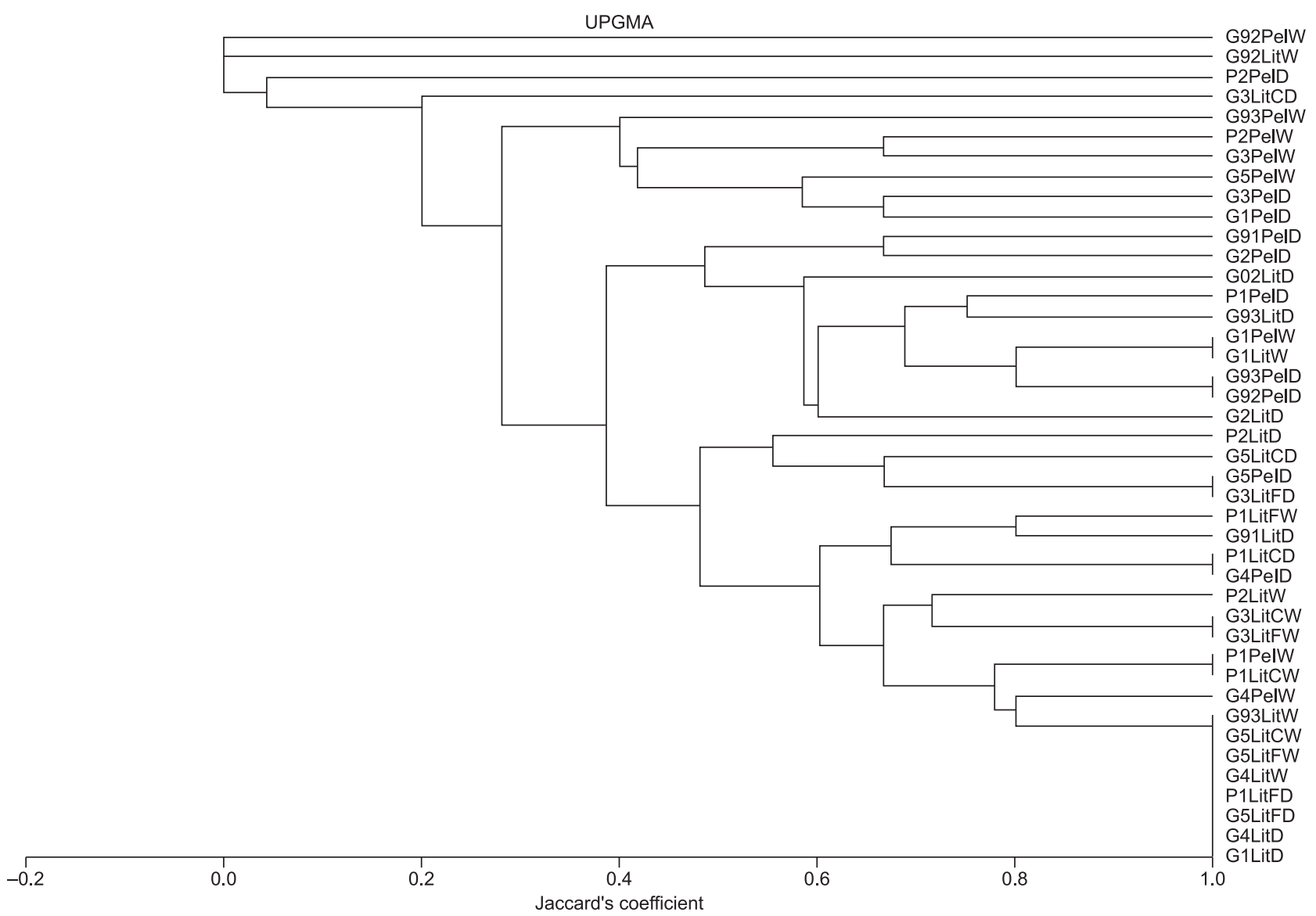

Figure 4. Similarity dendrogram of the Cladocera families between the sampling points at the dry and rainy season. $(\mathrm{Pel}=$ pelagic, $\mathrm{Lit}=$ littoral, $\mathrm{LitF}=$ littoral with forest, $\mathrm{LitC}=$ littoral with culture, $\mathrm{W}=$ rainy season, $\mathrm{D}=$ dry season).

Figura 4. Dendrograma de similaridade entre os pontos de amostragem nas zonas litorânea e pelágica, durante as estações seca e chuvosa, a partir de dados das familias de Cladocera. $(\mathrm{Pel}=$ pelágico, $\mathrm{Lit}=$ litoral, $\mathrm{LitF}=$ litoral com mata, LitC $=$ litoral com cultura, $\mathrm{W}=$ estação chuvosa, $\mathrm{D}=$ estação seca).

As previously reported, the northwestern region of São Paulo State is one of the least studied about zooplankton communities. It can be pointed out the works carried out by Silva \& Matsumura-Tundisi (2005) \& Santos-Wisniewski et al. (2008) on planktonic microcrustaceans from reservoirs of this region. For Rocha \& Guntzel (1999), cladocerans studies are still very limited for São Paulo State, whose lack of data allowed us to report some new occurrences of species for the State. These new records (see Table 3) were based on recent inventories that didn't found these species in São Paulo State (Elmoor-Loureiro 1997, 2000, Rocha \& Guntzel, 1999, SantosWisniewski et al. 2002, Martins \& Henry 2004, Casanova 2005, Santos-Wisniewski et al. 2008).

Species found in the present work were compared with those listed by Rocha \& Guntzel (1999). Of the 36 genus recorded in reservoirs of São Paulo State, only 10 were not found in the reservoirs of the northwestern region. Some genera like Ephemeroporus, Notoalona and Pseudochydorus are not included in the list of Rocha \& Guntzel (1999), but they are quoted by Elmoor-Loureiro (2000) $\&$ Santos-Wisniewski et al. (2008) for São Paulo State. The genera Leydigia was found in the present work as the first time for the state, but because the problems with the taxonomy of this specie (Kotov 2009), we prefer not to include as a new record.

This analysis allows us to suggest that the northwestern region of the São Paulo State presents high cladoceran species richness, representing ca. $68 \%$ of all the cladocerans richness of the State. This high richness opposes the high environmental degradation and deforestation of the region, which is considered the most devastated of the State (Kronka et al. 1993). The importance of sampling in littoral zones of the reservoirs is emphasized since all four new species records in the present work belong to Family Chydoridae, typical from the littoral region.

Our analyses also support the hypothesis already stated that microcrustaceans diversity in Brazil can be much higher than the reported at present, since most of limnological works on inventory are from pelagic zones (e.g. Rocha et al. 1995, Elmoor-Loureiro 2000, Nogueira et al. 2003). In these zones, Chydoridae, Macrothricidae and Ilyocriptidae are accidental. Samplings from the littoral plus the pelagic zones in the present work resulted in a cladoceran species list where these three families were $67 \%$ of all the richness observed.

Maia-Barbosa et al. (2008), studying the Lake D. Helvécio, found a great number of new records of microcrustaceans species and they attribute this fact to sampling in littoral zone and not only in the pelagic one, as previous works in the same lake.

The average number of cladoceran species was higher in northwest of São Paulo State than in previous works (Arcifa et al. 1992, 1998) where sampling was limited to pelagic zone at dry season. In small and shallow reservoirs at Serra da Mantiqueira, SantosWisniewski et al. (2002) found lower richness of Chydoridae species than the present study. On the other hand, richness and diversity were lower in the present work than that from oxbow lakes (Lima et al. 2003, Serafim et al. 2003, Martins \& Henry 2004, Casanova 2005). It is possible that in oxbow lakes the species diversity is 
influenced by the instability produced by the connection with the fluvial environment. Connectivity with lakes determines a high input of nutrients from river and can provide the establishment of a high number of zooplanktonic populations. The disturbance caused by the river influence in the oxbow lakes can be considered an intermediary disturbance, which, according to Begon et al. (2007), supports high species diversity. Disturbance studies comparing oxbow lakes and reservoirs will confirm the differences on the communities of these two kinds of environments (Castilho-Noll in prep.).

We found significant differences between the cladoceran species richness and diversity from littoral and pelagic zones, especially at the dry season. Because the turbulence in rainy season, microcrustaceans can be carried from the littoral to pelagic, becoming both zones similar. Grouping of several littoral sites, in cluster analysis evidenced differences between both zones, especially in species composition, which must be considered in studies on lentic environments.

High environmental heterogeneity favors high diversity of microhabitats resulting in species number increase (Begon et al. 2007). The littoral zones of freshwaters are very rich in microhabitats, due to the macrophytes presence. This feature results in high microcrustacean species diversity (Lemly \& Dimmick 1982, Nogueira et al. 2003) as also confirmed in the northwestern region of São Paulo State. Macrophytes presence in the littoral is probably a controlling factor, since cladocerans richness and diversity were higher in zones with elevated macrophytes diversity than that with a scarce macrophytes community. Other studies already linked high zooplankton diversity with high macrophytes diversity (Matsumura-Tundisi et al. 1990, Nunes et al. 1996, Maia-Barbosa et al. 2008) or a reduction in the number of invertebrates and vertebrates species with the disappearance of macrophytes banks (Timms \& Moss 1984). Eutrophication can also favor zooplankton diversity increase in the littoral zones (Lemly \& Dimmick 1982).

Species from the families Sididae, Moinidae, Daphniidae and Bosminidae are reported in literature as predominant among the pelagic Cladocera, Chydoridae and Macrothrycidae among littoral zones (Rocha \& Guntzel 1999). This fact was observed especially at the dry season in the present work, with similar families' spatial distribution proposed by Rocha \& Guntzel (1999).

Microcrustaceans' community of littoral freshwaters can be classified in three general groups: a) associated with macrophytes; b) free-swimming among aquatic plants; c) sessile, living mainly in littoral sediments (Wetzel 2001). Scraper feeders of periphyton can be found in Macrothricidae and Chydoridae and truly filter feeders in Sididae, Moinidae and Daphnidae (Elmoor-Loureiro 2007). In this way, macrothricids and chydorids found in the littoral zone at northwest of São Paulo State are probably scraper feeder species living in close association with macrophytes, while sidids, moinids and daphnids are filter feeders species free-swimming among aquatic plants.

In temperate shallow lakes, the diel horizontal migration (DHM) has been pointed as an alternative strategy of some cladocerans populations to avoid predation by planktivorous fishes and invertebrate (Lauridsen et al. 1996, Burks et al. 2002). Estlander et al. (2009) showed the importance of littoral zones as refuge in shallow lakes with high transparency. Very few works, however, have been studied the DHM in shallow lakes at tropical and subtropical regions (e.g. Meerhoff et al. 2006, Iglesias et al. 2007). According to Iglesias et al. (2007), in the tropics and subtropics, the effects of the macrophytes on trophic interactions are more complex than in temperate lakes. In shallow subtropical lakes, the aquatic plants offer refuge to zooplankton only when fishes and invertebrate predators are not abundant. In these cases, the benefits of the refuge among macrophytes must be balanced with the predators' behavior that also live associated to the macrophytes (Burks et al. 2002).

The presence of filter feeders as Diaphanosoma, Bosmina and Ceriodaphnia is common in temperate shallow lakes, where there is a close relation with submerged macrophytes (Vuille 1991, Wetzel 2001). In the shallow lakes studied in the present work, the presence of many filter feeders as Diaphanosoma, Ceriodaphnia, Moina, Daphnia and Bosmina in the littoral zone, as well as the significant association found between high cladocerans diversity and high macrophytes diversity, can suggest the DHM occurrence, when the cladocerans are using the littoral macrophytes as refuge against their predators. However, the lack of data on invertebrate and vertebrate predators in studied lakes, as well as the scarce of data on zooplankton DHM in other tropical shallow lakes, does not allow to test this hypothesis.

Supposing the occurrence of DHM in these reservoirs, at rainy season, the similarities between species composition in littoral and pelagic zones, besides the high abundance in the littoral of species typically pelagic, such as: Bosmina, Moina, Ceriodaphnia and Daphnia, can be related with changes in migratory behavior, which can be intense at summer, also because of the high richness and abundance of predators. The mixture of the zones by turbulence in rainy season can be also a plausible explanation as many typically littoral species could be also observed in pelagic zone.

Especially for tropical shallow lakes, data on the influence of the riparian forests loss on lentic communities are still scarce. Steedman et al. (1998) suggest that removing riparian forest, the thermal regime of the lentic environments can be modified, affecting mainly the littoral zones of shallow lakes. In another study, Garcia et al. (2007) found increases in the $\mathrm{MeHg}$ (Metyl Mercury) concentrations at zooplankton's tissues in boreal lakes impacted by deforestation. Deforestation impacts are well known and reported for the lotic environments, which are affected mainly by reduction of the littoral complexity and a high input of land sediments. Even though the lack of data from lentic environments, it is possible to suppose that deforestation negatively impacts the aquatic communities of lakes, especially those living at littoral zones. Observations from the present study can support this assumption, since low cladoceran species richness was found in littoral zones with cultures, compared to littoral with forest. The absence of the forest possibly allows high input of matter and sediments from terrestrial environment, resulting in increases of suspended material, perturbing the filter feeders development. In the present study, filter feeders as Daphnia, Ceriodaphnia and Diaphanosoma could be found only in littoral zones where there was a forest on the edge. In littoral zones without forest we found scraper feeders as Macrothricidae and Chydoridae, and typical zooplankton filter feeders could not be observed there.

In conclusion, even though they are small aquatic environments, the studied reservoirs showed a rich cladoceran fauna. Our data assume high importance considering that the reservoirs are in one of the most devastated regions of São Paulo State and part of the original fauna could be already lost. Comparisons between littoral and pelagic zones showed the importance of studying on the different compartments of the aquatic environments, confirming the high richness in the littoral already reported in other works. The study also showed the strong influence of the macrophytes community and the terrestrial adjacent environment on the cladoceran community.

\section{Acknowledgments}

We thank $1^{\text {st }}$ Company of the $4^{\text {th }}$ Battalion of Environmental Police officer of São José do Rio Preto for helping on part of the fieldwork, L.M.A. Elmoor-Loureiro for the partial identification of cladocerans 
and R. Henry for read and comments to the manuscript. We also thank anonymous referee for the suggestions.

This work is supported by grants from FAPESP (BIOTA/FAPESP Program, 04/04820-3) and a Post-doctoral fellowship to the senior author (07/05134-4).

\section{References}

ARCIFA, M.S. 1984. Zooplankton composition on ten reservoirs in Southern Brazil.Hydrobiologia. 113(1):137-145.

ARCIFA, M.S., GOMES, E.A.T. \& MESCHIATTI, A.J. 1992. Composition and fluctuations of the zooplankton of a tropical Brazilian reservoir. Archi. Hydrobiol. 123(4):479-495.

ARCIFA, M.S., SILVA, L.H.S. \& SILVA, M.H.L. 1998. The planktonic community in a tropical Brazilian reservoir: composition, fluctuations and interactions. Rev. Bras. Biol. 58(2):241-254

BEGON, M., TOWNSEND, C.R. \& HARPER, J.L. 2007. Ecologia: de indivíduos a ecossistemas. 4 ed. Artmed, Porto Alegre.

BURKS, R.L., LODGE, D.M., JEPPESEN, E. \& LAURIDSEN, T.L. 2002 Diel horizontal migration of zooplankton: costs and benefits of inhabiting the littoral. Freshwat. Biol. 47(3):343-365.

CASANOVA, S.M.C. 2005. Análise da estrutura da comunidade zooplanctônica na região de desembocadura do Rio Paranapanema na Represa de Jurumirim (SP), com ênfase na dinâmica populacional de Rotifera. Tese de Doutorado, Universidade Estadual de São Paulo, Botucatu.

ELMOOR-LOUREIRO, L.M.A. 1997. Manual de identificação de cladóceros límnicos do Brasil. Editora Universa, Brasília.

ELMOOR-LOUREIRO, L.M.A. 2000. Brazilian cladocerans studies: where do we stand? Nauplius. 8(1):117-131.

ELMOOR-LOUREIRO, L.M.A. 2007. Phytophilous cladocerans (Crustacea, Anomopoda and Ctenopoda) from Paraná River Valley, Goiás, Brazil. Rev. Bras. Zool. 24(2):344-352.

ELMOOR-LOUREIRO, L.M.A., MENDONÇA-GALVÃO, L. \& PADOVESIFONSECA, C. 2004. New cladoceran records from Lake Paranoá, Central Brazil. Brazil. J. Biol. 64(3A):415-422.

ESTLANDER, S., NURMINEN, L., OLIN, M., VINNI, M. \& HORPPILA, J. 2009. Seasonal fluctuations in macrophyte cover and water transparency of four brown-water lakes: implications for crustacean zooplankton in littoral and pelagic habitats. Hydrobiologia. 620(1):109-120.

GARCIA, E., CARIGNAN, R. \& LEAN, D.R.S. 2007. Seasonal and interannual variations in methyl mercury concentrations in zooplankton from boreal lakes impacted by deforestation or natural forest fires. Environ. Monit. Assess. 131:1-11

HENRY, R. \& NOGUEIRA, M.G. 1999. A represa de Jurumirim (São Paulo): primeira síntese sobre o conhecimento limnológico e uma proposta preliminar de manejo ambiental. In Ecologia de reservatórios: estrutura, função e aspectos sociais (R. Henry, ed.) FAPESP; FUNDIBIO, Botucatu, p. 651-685.

IGLESIAS, C., GOYENOLA, G., MAZZEO, N., MEERHOFF, M., RODÓ, E. \& JEPPESEN, E., 2007. Horizontal dynamics of zooplankton in subtropical Lake Blanca (Uruguay) hosting multiple zooplankton predators and aquatic plant refuges. Hydrobiologia. 584(1):179-189.

ISMAEL, D., VALENTI, W.C., MATSUMURA-TUNDISI, T., ROCHA, O. 1999. Biodiversidade do Estado de São Paulo, Brasil: síntese do conhecimento ao final do século XX. FAPESP, São Paulo. (v. 4, Invertebrados de Água Doce)

KOVACH, W.L. 1993. MVSP A Multi Variate Statistical Package for IBMPCs, ver 2.1. Kovach Computing Services, Pentraeth, Wales, UK.

KRONKA, F.J.N., MATSUKUMA, C.K., NALON, M.A., DELCALI, I.H., ROSSI, M., MATTOS, I.F.A., SHIN-IKE, M.S. \& PONTINHAS, A.A.S 1993. Inventário florestal do Estado de São Paulo. Instituto Florestal, São Paulo.

LAURIDSEN, T.L., PEDERSEN, L.J., JEPPESEN, E. \& SONDERGAARD, M. 1996. The importance of macrophyte bed size for cladoceran composition and horizontalmigration in a shallow lake. J. Plankton Res. 18(12):2283-2294.

LEMLY, A.D. \& DIMMICK, J.F. 1982. Structure and dynamics of zooplankton communities in the littoral zone of some North Caroline lakes. Hidrobiologia. 88(3):299-307.

LIMA, A.F., LANSAC-TÔHA, F.A., VELHO, L.F.M., BINI, L.M. \& TAKEDA, A.M. 2003. Composition and abundance of Cladocera (Crustacea) assemblages associated with Eichhornia azurea (Swartz) Kunth stands in the Upper Paraná River floodplain. Maringá. 25(1):41-48.

MAGURRAN, A.E. 2004. Measuring biological diversity. Blackwell Publishing, Malden.

MAIA-BARBOSA, P.M., PEIXOTO, R.S. \& GUIMARÃES, A.S. 2008 Zooplankton in littoral waters of a tropical lake: a revisited biodiversity. Braz. J. Biol. 68(suppl. 4):1069-1078.

MARTINS, G.M. \& HENRY, R. 2004. Composição e abundância do Zooplâncton em três lagoas laterais ao Rio Paranapanema na zona de sua desembocadura na Represa de Jurumirim (São Paulo). In Ecologia aquática tropical (S. Chellapa, N.T. Chellapa \& J.Z.O. Passavante, eds.) Sergraf, Natal, p. 53-72.

MATSUMURA-TUNDISI, T. 1984. Occurrence of species of the genus Daphnia in Brazil. Hydrobiologia. 112(3):161-165.

MATSUMURA-TUNDISI, T., LEITÃO, S.N.,AGHENA, L.S. \& MIYAHARA, J. 1990. Eutrofização da represa de Barra Bonita: estrutura e organização da comunidade de Rotifera. Rev. Bras. Biol. 50(4):923-935.

MATSUMURA-TUNDISI, T. \& ROCHA, O. 1983. Occurrence of copepod (Calanoida, Cyclopoida and Harpacticoida) from "Broa" Reservoir (São Carlos, São Paulo, Brazil). Rev. Bras. Biol. 43(1):1-17.

MCCAULEY, E. 1984. The estimation of the abundance and biomass of zooplankton in samples. In A manual on methods for the assessment of secundary productivity in fresh waters (J.A. Downing \& F.H. Rigler, eds.). Blackwell Scientific Publications, London, p. 228-265.

MEERHOFF, M., FOSALBA, C., BRUZZONE, C., MAZZEO, N., NOORDOVEN, W. \& JEPPESEN, E. 2006. An experimental study of habitat choice by Daphnia: plants signal danger more than refuge in subtropical lakes. Freshwat. Biol. 51(7):1320-1330.

NOGUEIRA, M.G., GEORGE, D.G. \& JORCIN, A. 2003. Estudo do zooplâncton em zonas litorâneas lacustres: um enfoque metodológico. In Ecótonos nas interfaces dos ecossistemas aquáticos (R. Henry, org.) Rima, São Carlos, p. 81-126.

NUNES, M.A., LANSAC-TÔHA, F.A., BONECKER, C.C., ROBERTO, M.C. \& RODRIGUES, L. 1996. Composição e abundância do zooplâncton de duas lagoas do Horto Florestal Dr. Luiz Teixeira Mendes, Maringá, Paraná. Acta Limnol. Brasil. 8: (1):207-220.

ROCHA, O., SENDACZ, S. \& MATSUMURA-TUNDISI, T. 1995. Composition, biomass and productivity of zooplankton in natural lakes and reservoir of Brasil. In Limnology in Brazil (J.G. Tundisi, C.E.M. Bicudo \& T. Matsumura-Tudisi, eds.). ABC; SBL, Rio de Janeiro, p. 151-165.

ROCHA, O. \& GÜNTZEL, A. 1999. Crustáceos Branchiopodos. In Biodiversidade do Estado de São Paulo, Brasil: síntese do conhecimento ao final do século XX (D. Ismael, W.C. Valenti, T. Matsumura-Tundisi, \& O. Rocha, eds.). FAPESP, São Paulo, p. 107-20. (v. 4, Invertebrados de Água Doce)

SANTOS-WISNIEWSKI, M.J., ROCHA, O., GÜNTZEL, A.M. \& MATSUMURA-TUNDISI, T. 2002. Cladocera Chydoridae of high altitude water bodies (Serra da Mantiqueira) in Brazil. Braz. J. Biol. 62(4A):681-687.

SANTOS-WISNIEWSKI, M.J., ROCHA, O., GUNTZEL, A.M. \& MATSUMURA-TUNDISI, T. 2008. Species richness and geographic distribution of the genera Chydorus and Pseudochydorus (Cladocera, Chydoridae) in São Paulo State. Biota Neotrop. 8(1): http://www. biotaneotropica.org.br/v8n1/en/abstract?article+bn01308012008 (último acesso em 20/01/2009).

SENDACZ, S. 1984. A study of the zooplankton community of Billings Reservoir: São Paulo. Hydrobiologia. 113(1):121-127. 
SENDACZ, S. \& KUBO, E. 1999. Zooplâncton de reservatórios do Alto do Tietê, Estado de São Paulo. In Ecologia de reservatórios: estrutura, função e aspectos sociais (R. Henry, ed.). FAPESP, São Paulo, p. 509-530.

SERAFIM, M. JUNIOR., BONECKER, C.C., ROSSA, D.C., LANSAC TÔHA, F.A. \& COSTA, C.L. 2003. Rotifers of the upper Paraná river floodplain: additions to the checklist. Braz. J. Biol. 63(2):207-212.

SILVA, W.M. \& MATSUMURA-TUNDISI, T. 2005. Taxonomy, ecology and geographical distribution of the species of the genus Thermocyclops Kiefer, 1927 (Copepoda, Cyclopoida) in São Paulo State, Brazil, with description of a new species. Braz. J. Biol. 65(3):521-531.

SMIRNOV, N.N. 1996. Cladocera: the Chydorinae and Sayciinae (Chydoridae) of the world. SPB Academic Publishing BV, Belgium.

STEEDMAN, R.J. FRANCE, R.L., KUSHNERIUK, R.S. \& PETERS, R.H. 1998. Effects of riparian deforestation on littoral water temperatures in small Boreal forest lakes. Boreal Env. Res. 3:161-169.

STRASKRABA, M., TUNDISI, J.G. \& DUNCAN, A. 1993. State-of-the-art of reservoir limnology and water quality management. In Comparative reservoir limnology and water quality management (M. Straskraba, J.G. Tundisi \& A. Duncan, eds.). Kluwer Academic Publisher, Dordrecht, p. 213-288.

TUNDISI, J.G. \& MATSUMURA-TUNDISI, T. 2008. Limnologia. Oficina de Textos, São Paulo.

TIMMS, R.M. \& MOSS, B. 1984. Prevention of growth of potentially dense phytoplankton populations by zooplankton grazing, in the presence of zooplanktivorous fish, in a shallow wetland ecosystem. Limnol. Oceanogr. 29(3):472-486.

VUILLE, B. 1991. Abundance, standing crop and production of microcrustacean population (Cladocera, Copepoda in the littoral zone of Lke Biel, Switzerland. Arch. Hydrobiol. 123(2):165-185.

WETZEL, R.G. 2001. Limnology lake and river ecosystems. 3 ed. Elsevier Academic Press, London.

Received 04/05/09

Revised 14/12/09

Accepted 01/01/10 